\title{
Perencanaan dan Desain Lanskap Embung Mekar Sari Kabupaten Tulang Bawang Barat Berbasis Budaya Lampung
}

\author{
Eduwin Eko Franjaya ${ }^{1^{*}}$ \\ ${ }^{1}$ Lab Perencanaan \& Desain Lanskap, Program Studi Arsitektur Lanskap, Jurusan Teknologi Infrastruktur dan Kewilayahan, Institut \\ Teknologi Sumatera \\ *Penulis Korespondensi: eduwin.franjaya@arl.itera.ac.id; Telp. +62 819-2939-2001
}

\begin{abstract}
Abstrak:
Kabupaten Tulang Bawang Barat (Tubaba) merupakan kabupaten baru pengembangan dari Kabupaten Tulang Bawang. Kabupaten ini diresmikan pada tahun 2008. Dengan status kabupaten baru, Tulang Bawang Barat perlu melakukan penataan ruang dan wilayahnya agar dapat mendukung sosial perekonomian daerah. Berdasarkan peraturan daerah Kabupaten Tulang Bawang Barat Nomor 2 tahun 2012 tentang tata ruang, salah satu yang dikembangkan adalah kawasan wisata, baik wisata buatan, alam maupun budaya. Keberadaan beberapa embung yang ada di daerah ini turut menjadi fokus pengembangan obyek wisata. Tujuan penelitian ini adalah menganalisis dan merancang Site Plan dan desain kawasan wisata Embung Mekar Sari Kabupaten Tulang Bawang Barat dengan mengambil ciri budaya Provinsi Lampung. Metode yang digunakan adalah kualitatif deskriptif dengan pendekatan perencanaan dan perancangan arsitektur lanskap. Hasil dari penelitian ini berupa gambar rancangan Site Plan kawasan Wisata embung secara umum, 3D desain dan Video Animasi kawasan wisata Embung Mekar Sari. Hasil penelitian ini diharapkan dapat menjadi masukan bagi pemerintah Kabupaten Tulang Bawang Barat, terutama dalam hal pengembangan wilayah yang sesuai dengan kondisi tapak dan sosial budayanya.
\end{abstract}

Kata Kunci: budaya lampung; embung; site plan; wisata; 3D desain

\section{Latar Belakang}

Kabupaten Tulang Bawang Barat (Kab. Tubaba) yang berada di Provinsi Lampung merupakan Kabupaten pengembangan dari Kabupaten Tulang Bawang. Kabupaten ini diresmikan tahun 2008. Dalam prosesnya, pemerintah terus mengembangkan wilayah ini dengan mengacu pada UU Nomor 26 Tahun 2007 tentang Penataan Ruang yang kemudian diturunkan menjadi Peraturan Daerah Kabupaten Tulang Bawang Barat Nomor 2 Tahun 2012 tentang Rencana Tata Ruang Wilayah Kabupaten Tulang Bawang Barat Tahun 2011-2031: "Rencana penyediaan dan pemanfaatan RTH di Kabupaten Tulang Bawang Barat termuat dalam perencanaan pengembangan kawasan pariwisata. Peruntukan pengembangan wisata sebagaimana dimaksud dalam Pasal 41 ayat (3) meliputi pengembangan dan peningkatan aksesibilitas pendukung pada wisata buatan, wisata alam dan wisata budaya; peningkatan peran serta masyarakat pada daerah potensi wisata, serta menyusun rencana pengembangan pariwisata." Perda yang berisikan rencana pengembangan pariwisata tersebut menjadi salah satu dasar dalam pengembangan wisata Embung Mekar Sari.

Pemerintah daerah Kab Tubaba pada awalnya mengajukan beberapa embung untuk dikembangkan. Namun, berdasarkan studi kelayakan yang dilakukan oleh tim dari Institut Teknologi Sumatera, hanya 3 embung yang memenuhi syarat dan Embung Mekar Sari adalah salah satu diantaranya. Pemerintah daerah juga memberikan gambaran pengembangan yang mereka inginkan yang kemudian nantinya akan diolah, dianalisis, dan didesain oleh perencana dan desainer lanskap.

Penelitian ini bertujuan untuk menganalisis dan merancang site plan dan desain kawasan wisata Embung Mekar Sari Kabupaten Tulang Bawang Barat dengan mengambil ciri budaya Provinsi Lampung. Ciri budaya yang akan diambil dapat berupa motif, ornamen atau penciri khas budaya lainnya. Warna yang identik dengan budaya Lampung juga dapat digunakan dalam perancangan. Motif dan warna ini dapat diterapkan pada elemen softscape maupun elemen hardscape. Penggunaan motif dan warna yang berkaitan dengan budaya lampung pada perencanaan dan desain Embung Mekar Sari ini diharapkan dapat menjadi identitas desain lanskap yang khas dan tidak dapat ditemukan pada lanskap lainnya.

\section{Metode}

Metode yang digunakan pada penelitian ini adalah metode kualitatif deskriptif dengan pendekatan Perencanaan dan Perancangan Lanskap. 


\subsection{Metode Kualitatif Deskriptif}

Metode ini digunakan dalam penelitian dengan penekanan pada analisis data penunjang dan pemrosesan makna secara subyektif oleh peneliti sekaligus perencana dan desainer lanskap. Hasil analisis dari metode ini kemudian dikaitkan dengan metode atau pendekatan dalam perencanaan dan perancangan lanskap sehingga menjadi satu kesatuan metode. Hal ini diharapkan akan memperkuat hasil penelitian sekaligus desain yang akan dihasilkan.

Penggunaan metode kualitatif deskriptif ini ditekankan terutama pada analisis budaya Provinsi Lampung sebagai ruh/nyawa dari konsep desain lanskap. Pengumpulan informasi dan data terkait budaya Lampung didapat melalui kunjungan ke Museum Lampung dan beberapa buku referensi.

\subsection{Pendekatan Perencanaan dan Perancangan Lanskap}

Metode ini biasa digunakan dalam melakukan perencanaan dan perancangan arsitektur lanskap. Pada dasarnya metode ini merupakan tahapan-tahapan dalam melakukan proses merencana dan merancang, mulai dari inventarisasi hingga desain dan visualisasi. Tahapan desain dalam penelitian ini sebagaimana pada Gambar 1.

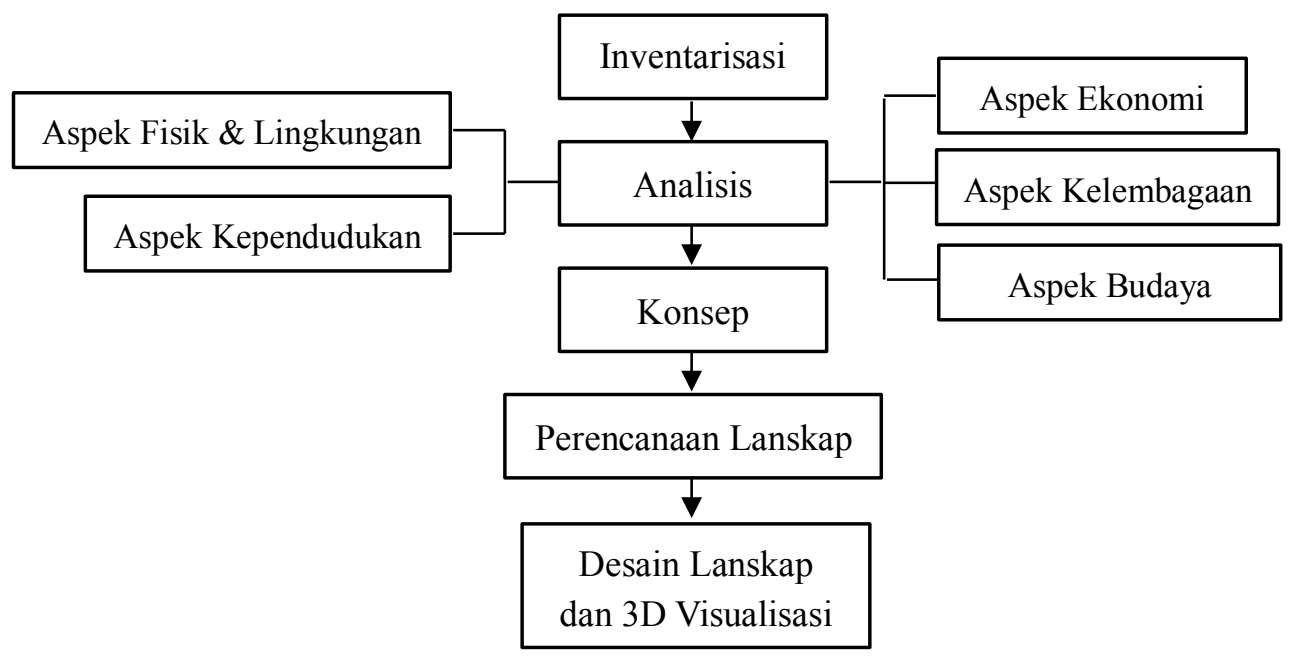

Gambar 1. Tahapan desain

Pada tahap inventarisasi, dikumpulkan data-data yang berkaitan dengan lokasi penelitian secara umum, terutama kondisi eksisting embung. Selain itu pada tahap ini juga dikumpulkan informasi terkait dengan motif atau ornamen khas Lampung. Motif dan ornamen ini akan dimanfaatkan pada tahap pengerjaan konsep desain dan konsep pengembangan.

Data-data yang telah dikumpulkan dari berbagai sumber pada tahap inventarisasi kemudian diolah dan dianalisis. Terdapat 5 (lima) aspek yang akan dianalisis, yakni aspek fisik \& lingkungan, aspek kependudukan, aspek ekonomi, aspek kelembagaan, dan aspek budaya.

Pada tahap konsep, dirumuskan konsep utama dari pengembangan tapak. Dari konsep utama ini kemudian dilengkapi dengan konsep desain dan konsep pengembangan yang lebih mendetil. Konsep pengembangan merupakan aplikasi dari konsep dasar/utama dan konsep desain (Franjaya EE, 2013). Konsep pengembangan ini diantaranya adalah konsep ruang/zonasi, konsep fasilitas dan atraksi wisata, konsep elemen hardscape dalam kaitannya dengan budaya Lampung dan konsep elemen softscape yang juga berkaitan dengan budaya Lampung.

Setelah konsep dirumuskan, selanjutnya adalah merancang site plan embung Mekar Sari. Site plan dibuat dengan memanfaatkan aplikasi CAD 2D sederhana yang kemudian dianjutkan dengan finishing menggunakan photoshop. Hasilnya berupa gambar site plan 2D Embung Mekar Sari dengan view sekitar diambil menggunakan Google Earth.

Site plan yang sudah dibuat menjadi acuan dalam membuat gambar desain lanskap dan 3D visualisasi. Gambar 3D yang dibuat terlebih dahulu adalah 3D kontur dari area wisata embung. 3D kontur ini penting untuk menunjukkan ilustrasi suasana real sebagaimana terlihat di lapang. Kontur ini disesuaikan dengan rencana pengembangan. Gambar 3D visualisasi memanfaatkan aplikasi CAD, Sketch-up, dan Lumion.

\section{Hasil dan Pembahasan}

Terdapat berbagai hasil yang didapat berdasarkan masing-masing tahapan desain yang disebutkan di atas. Hasil tersebut dibahas per masing-masing tahapan untuk kemudian dilakukan perencanaan dan desain lanskap. 


\subsection{Inventarisasi}

Berdasarkan hasil inventarisasi secara umum, didapat informasi bahwa tapak penelitian didominasi oleh badan air/embung. Embung ini dikelilingi oleh tanaman perkebunan terutama karet (Hevea brasiliensis). Kontur tapak cukup bergelombang. Akses lokasi tapak cukup dekat dengan permukiman warga desa, dengan jarak akses dari jalan utama desa berkisar antara 200-300 m. Tapak belum dimanfaatkan secara berlebih dan masih dalam kondisi alaminya, terutama embung.

Terkait budaya Lampung, berdasarkan buku Adat Istiadat Daerah Lampung (2016), masyarakat lampung merupakan masyarakat yang berbudaya dan memiliki kekayaan budaya yang masih dipegang teguh. Masyarakat adat Lampung secara umum beradatkan pepadun dan saibatin. Tatanan hidup yang ada pada masyarakat Lampung tidak hanya berupa ritual budaya, namun juga memiliki falsafah yang disebut dengan istilah Pi'il Pesenggiri. Pi'il berasal dari bahasa arab yang artinya perilaku, sedangkan pesenggiri artinya moral yang tinggi.

Budaya pada masyarakat Lampung sangat luas, tidak hanya tercermin dalam bahasa namun juga dalam seluruh aspek kehidupan, termasuk alat-alat yang digunakan dalam bekerja. Dari aspek bahasa, terdapat aksara lampung yang dapat menjadi inspirasi dalam mengembangkan konsep hardscape. Bentuk geometris dari motif perahu pada beberapa kain adat lampung dapat juga dijadikan ide pembuatan elemen hardscape berupa sculpture. Dalam arsitektur bangunan tradisional Lampung juga didapati penerapan desain perahu dalam benuk desain ujung balok lantai pada lamban bangsawan (Syarief R, 2012). Warna dalam budaya Lampung juga menarik untuk dicermati. Seperti 3 warna pada hiasan payung pada upacara-upacara adat Lampung. Warna tersebut adalah merah, kuning, dan putih. Warna-warna ini dapat diterapkan pada warna bangunan atau pemilihan tanaman-tanaman bunga. Ideide motif tersebut dapat diterapkan pada desain lanskap Embung Mekar Sari.

\subsection{Analisis}

Berdasarkan aspek fisik \& lingkungan, Embung Mekar Sari berada di lokasi strategis antara Jalan Tol Trans Sumatera dan Jalan Lintas Sumatera (Jalan Arteri Primer), sehingga memiliki potensi untuk menarik minat wisatawan dari dalam maupun luar kota. Dari sisi guna lahan, penggunaan lahan di sekitar embung didominasi oleh perkebunan masyarakat dan terdapat kelompok permukiman berkepadatan rendah dengan pola linear mengikuti jaringan jalan. Dari sisi kebencanaan, lokasi ini berpotensi kecil akan terjadinya bencana alam baik itu tanah longsor, banjir, gempa bumi, maupun gerakan tanah.

Dari aspek kependudukan, secara umum hasil analisis proyeksi penduduk kedepannya akan terus bertambah secara signifikan. Jika dilihat dengan skala yang lebih luas yakni kecamatan Lambu Kibang, pada 2023 jumlah penduduk akan mencapai 22.908 jiwa. Dari aspek ekonomi, sektor pertanian masih menjadi mata pencaharian pokok penduduk Kab Tubaba. Selain pertanian, sektor perdagangan dan industri menjadi sektor penunjang perekonomian. Dari aspek kelembagaan, terdapat beberapa lembaga yang memiliki wewenang terkait tapak, yakni BAPPEDA, Dinas PU, dan Balai Besar Wilayah Sungai Mesuji Sekampung.

Dari aspek budaya, bentukan geometris perahu yang tegas dapat menjadi sculpture yang menarik jika disusun dengan proporsional. Terkait tanaman lanskap, terdapat tanaman yang dijadikan tanaman identitas Provinsi Lampung, yakni Mirabilis jalapa atau dengan nama lokal Bunga Pukul empat/Bunga Sore/Bunga Ashar. Namun tidak semua area akan menerapkan tanaman ini, karena struktur tanamannya hanya berupa semak rendah. Oleh karena itu untuk tanaman hias akan menerapkan corak warna budaya lampung, yakni tanaman dengan bunga merah, kuning, dan putih.

\subsection{Konsep}

Konsep utama dari pengembangan tapak ini adalah wisata rekreasi dan edukasi. Konsep ini merupakan gambaran yang juga diinginkan oleh pemerintah terhadap pengembangan tapak. Hal ini kemudian akan mempengaruhi pada penetapan zonasi area. Konsep desain juga akan banyak berkaitan dengan atraksi dan fasilitas-fasilitas wisata yang diinginkan pada tapak. Untuk pola desainnya, akan mengambil beberapa pola dari budaya lampung, yakni bentukan geometris perahu dan pola warna pada payung adat (Gambar 2).

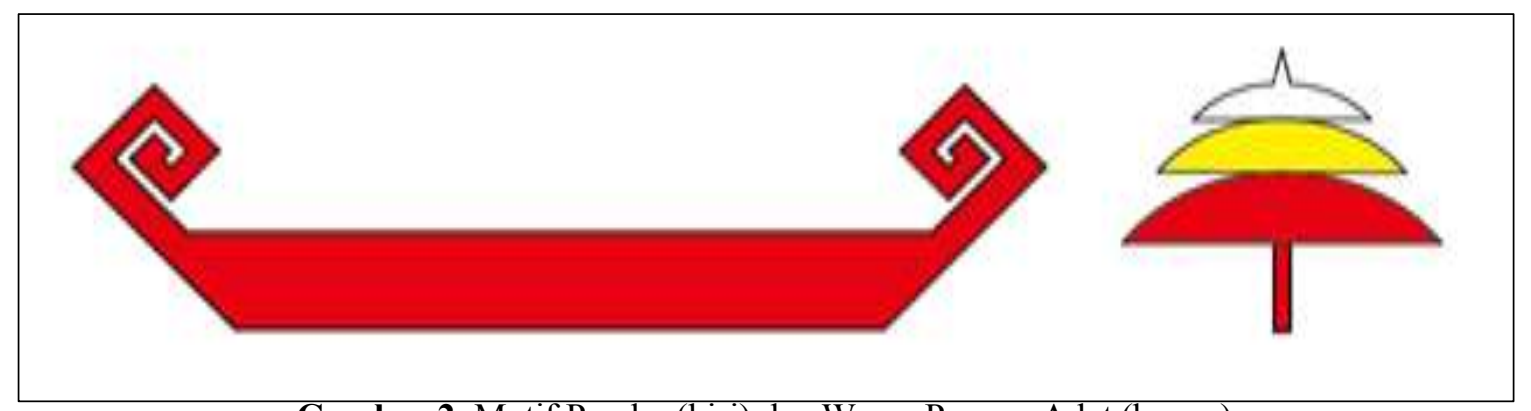

Gambar 2. Motif Perahu (kiri) dan Warna Payung Adat (kanan) 
Tapak dibagi menjadi beberapa zona, berurutan mulai dari entrance yakni zona penerimaan/pelayanan, zona taman batu 1, zona children playground (CPG), zona taman batu 2, zona mini resto, zona amphiteather dan deck pandang/ deck perahu, zona ecopark bambu, dan zona taman batu 3. Pembagian zona ini juga berdasarkan hasil koordinasi dengan pemerintah sebagai pengelola sekaligus mewakili masyarakat sebagai pengguna. Fasilitasnya antara lain yakni gerbang dan area parkir, toko souvenir, taman batu, taman bermain anak, resto bambu, deck pandang, perahu-perahuan, amphiteather, serta taman ekologis/ecopark. Konsep bentukan geometris perahu akan diterapkan sebagai sculpture pada taman batu. Terdapat 3 taman batu dengan masing-masing taman diwakili oleh tanaman hias bercorak warna merah, kuning, dan putih.

\subsection{Perencanaan Lanskap}

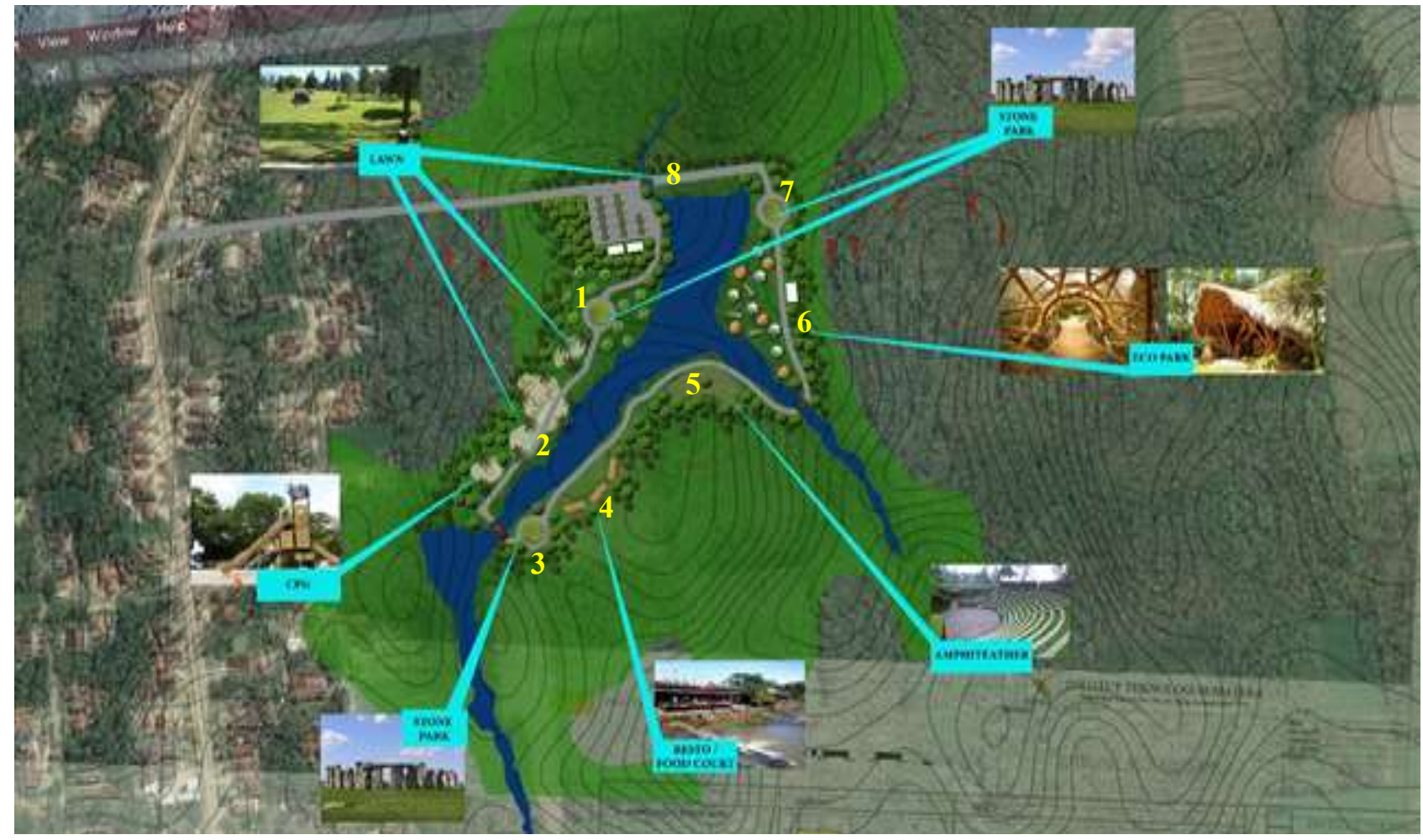

Gambar 3. Site Plan embung Mekar Sari

Gambar di atas adalah gambar site plan pengembangan Embung Mekar Sari. Angka 1 pada site plan menunjukkan area Taman Batu 1 dengan scupture batu bentukan geometris perahu dikelilingi oleh tanaman bernuansa merah. Angka 2 pada site plan menunjukkan area Children Playground (CPG). Angka 3 menunjukkan area Taman Batu 2 dengan sculpture batu motif geometris perahu dikelilingi tanaman semak warna kuning. Angka 4 pada site plan menunjukkan area Mini Resto dengan fasad bangunan bermotif bambu. Angka 5 menunjukkan area amphiteather dan deck pandang ke embung. Angka 6 pada site plan menunjukkan area eco park bambu.

Pada area ini ditanami beberapa jenis bambu sesuai permintaan pemerintah daerah. Selain berupa tanaman, bambu pada ecopark ini ditunjukkan juga dalam bentuk scupture, area bermain, dan penggunaan lainnya. Angka 7 menunjukkan Taman Batu 3 dengan sculpture batu yang dikelilingi tanaman bernuansa warna putih sesuai corak warna Lampung. Angka 8 merupakan area terakhir yang bisa dikunjungi, yakni berupa taman pandang. 


\subsection{Desain Lanskap dan 3D visualisasi}

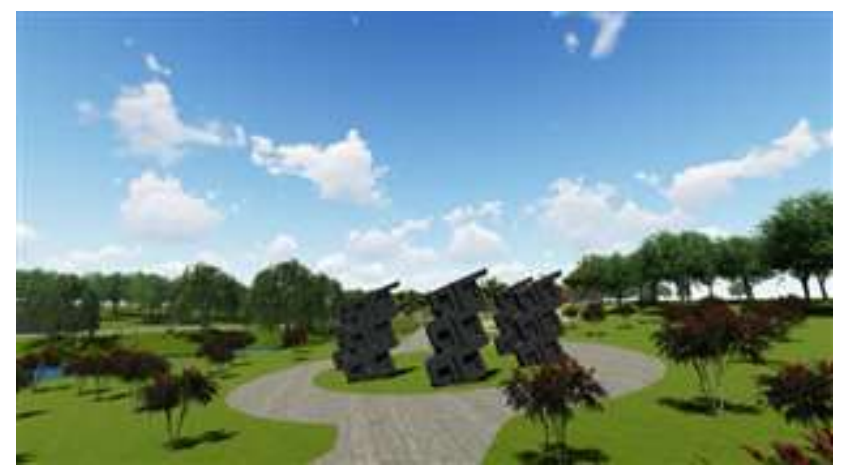

Gambar 4. Scupture Batu di Taman Batu 1

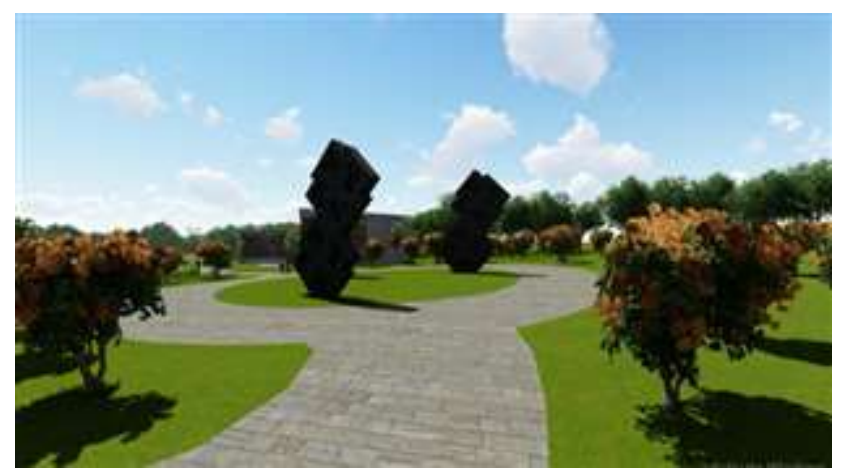

Gambar 6. Sculpture Batu di Taman Batu 2

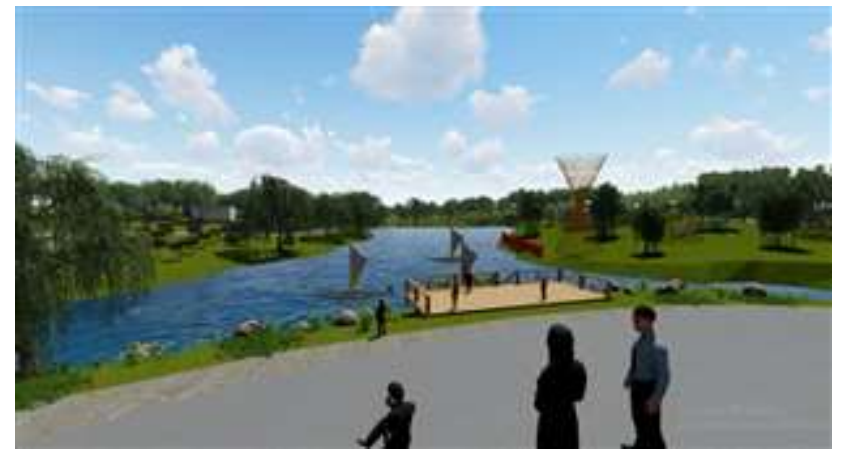

Gambar 8. Amphiteather dan Dek Pandang

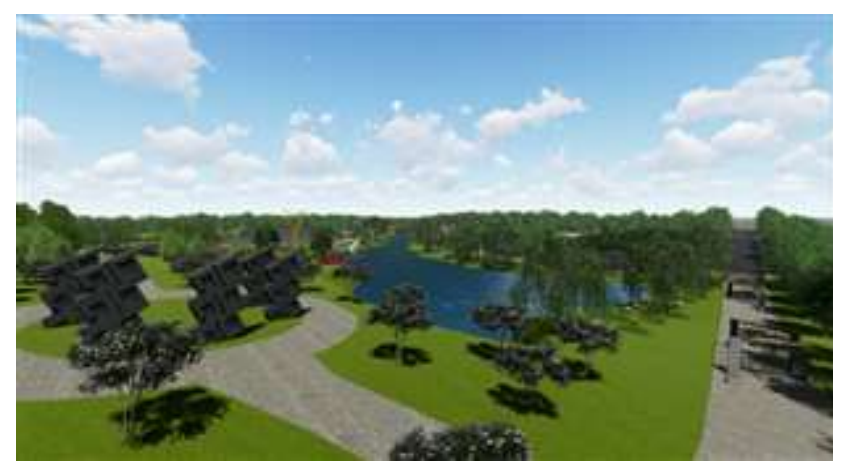

Gambar 10. Sculpture Batu pada Taman Batu 3

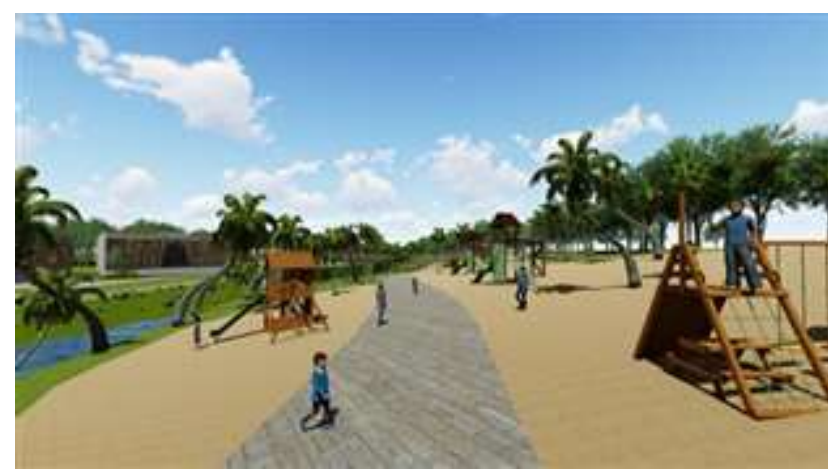

Gambar 5. Children Playground/Taman Bermain

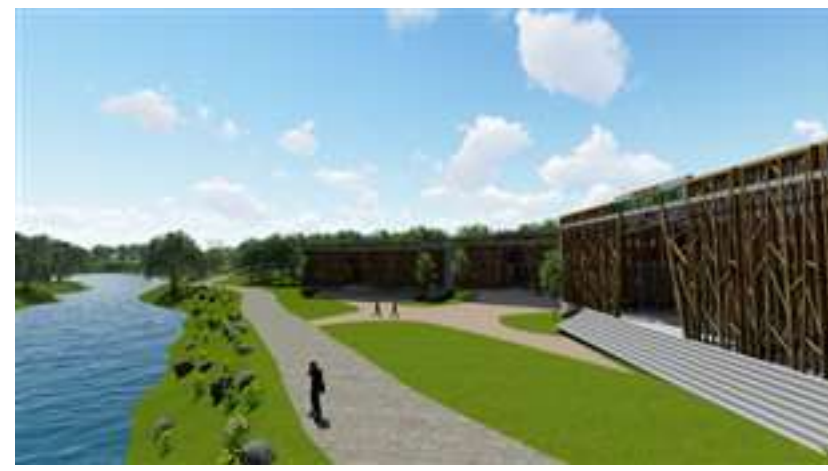

Gambar 7. Area Mini Resto berkonsep Bambu

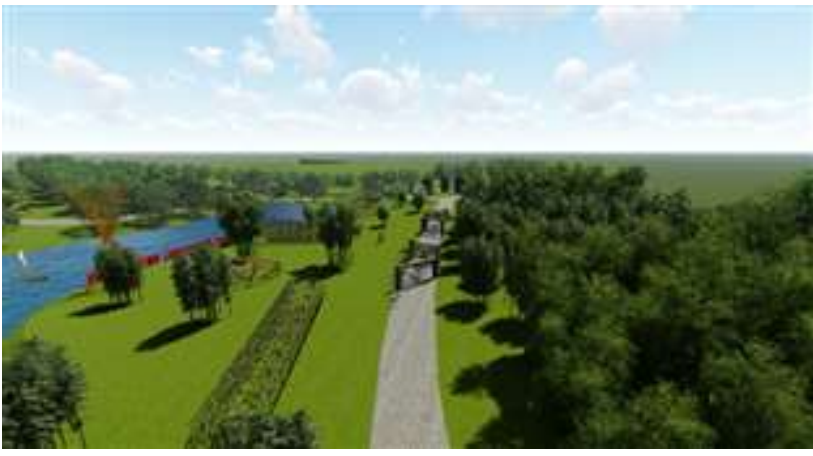

Gambar 9. Eco-park Bambu

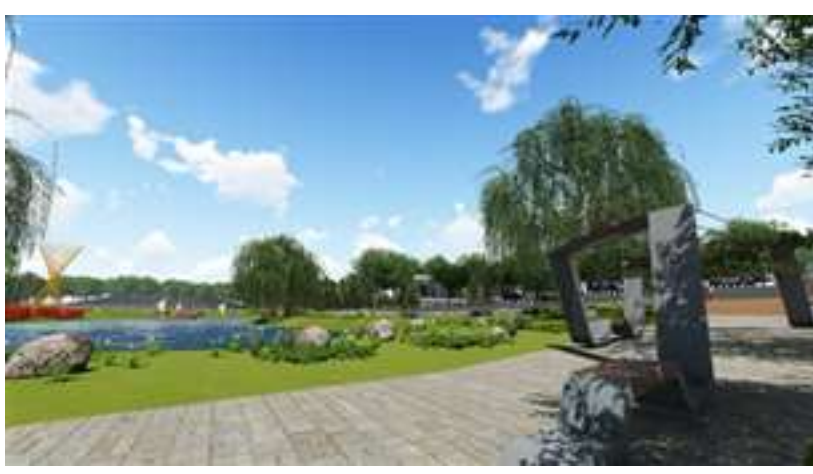

Gambar 11. Taman Pandang

Desain pada Gambar 4 adalah Taman Batu 1. Desain sculpture di taman batu merupakan bentuk transformasi/gabungan dari pola geometris pada motif perahu. Di sekeliing taman batu 1 ini ditanam tanaman dengan bunga berwarna merah sebagai representasi salah satu warna pada payung adat Lampung. Tanaman yang dipilih adalah dari jenis perdu atau semak, baik semak tinggi atau sedang. Pemilihan jenis ini penting untuk 
memastikan bahwa sculpture batu lebih tinggi dan dapat dilihat dari segala sisi. Hal ini merepresentasikan bahwa sculpture batu merupakan focal point yang diperkuat dengan taman disekitarnya. Posisi Taman Batu 1 tepat setelah area parkir/penerimaan.

Gambar 5 merupakan children playground (CPG). Area ini sebagai salah satu fasilitas untuk mengakomodasi pengguna dari kalangan anak-anak/ orang tua yang memiliki anak. Alat bermain yang digunakan disesuaikan dengan standar yang ada. Posisi area CPG ini tepat berada setelah Taman Batu 1. Taman Batu 2 pada Gambar 6 dapat ditemui setelah area CPG. Taman Batu 2 ini pada dasarnya menempatkan obyek material yang sama seperti Taman Batu 1 namun dengan bentuk sculpture yang sedikit berbeda dan dengan warna bunga yang berbeda. Warna tanaman bunga yang diaplikasikan adalah bunga berwarna kuning sebagai salah satu warna lain dari payung adat lampung. Setelah Taman Batu 2, kita akan menjumpai mini resto berkonsep bambu (Gambar 7). Mini resto ditempatkan diantara 2 area atau obyek dengan aktivitas yang aktif, yakni area CPG dan area berperahu di embung. Penempatan ini berguna untuk mempermudah akses bagi pengunjung setelah beraktivitas yang aktif. Konsep Bambu pada bangunan mini resto merupakan representasi dari Tanaman Bambu sebagai tanaman yang telah dan sedang terus dikembangkan di wilayah Kabupaten Tulang Bawang Barat. Konsep Bambu ini juga selaras dengan konsep ecopark bambu pada Gambar 9.

Area amphiteather dan deck pandang/ deck perahu pada Gambar 8 merupakan area yang sangat strategis dengan view yang sangat bagus yakni view terbuka menghadap embung, area CPG, dan area ecopark. Area ini mengakomodir aktivitas aktif sekaligus pasif. Aktivitas aktif yakni berperahu, dan pasif yakni duduk dan memandang area embung dan sekitar. Area selanjutnya yakni pada Gambar 9 adalah area ecopark. Area ini berfungsi sebagai area edukasi, bermain, sekaligus konservasi tanaman bambu. Tanaman yang ditanam pada area ini didominasi oleh tanaman bambu dengan berbagai jenis. Sebagian besar merupakan tanaman bambu yang juga dikembangkan/ dibudidayakan di daerah Kabupaten Tulang Bawang Barat. Pada area ini, masyarakat dapat bermain sekaligus belajar mengenai tanaman bambu mulai dari hulu dan hilir. Hulu dan hilir yang dimaksud disini adalah mulai dari jenis dan proses pertumbuhan tanaman bambu hingga penggunaan tanaman bambu sebagai material konstruksi bangunan. Pada penerapan nantinya, akan ada papan interpretasi yang membantu masyarakat/ pengunjung area ini untuk memahami perihal tanaman bambu.

Selanjutnya adalah Taman Batu 3 (Gambar 10) dengan sculpture batu yang sama dengan Taman Batu 1 namun dengan jenis tanaman berbunga yang berbeda. Tanaman berbunga pada Taman Batu 3 adalah tanaman dengan bunga warna putih. Warna ini melengkapi tiga warna pada payung adat lampung sekaligus warna yang mewakili Provinsi Lampung. Pada tahap akhir, pengunjung/ pengguna area wisata akan menjumpai taman pandang (Gambar 11). Pada taman ini pengunjung dapat beristirahat sejenak sebelum mengakhiri kunjungan. Pengunjung dapat duduk pada furniture bangku taman yang didesain kreatif sebagai satu kesatuan yang menyatukan dua bagian jalan yakni kiri dan kanan jalan. Hal ini merepresentasikan persatuan dari dua masyarakat adat utama di Lampung yakni masyarakat adat Pepadun dan Saibatin.

\section{Kesimpulan}

Budaya daerah Provinsi Lampung memiliki nilai kekayaan identitas yang sangat berharga dan tidak ada duanya di dunia. Penerapan nilai budaya dalam perencanaan dan perancangan lanskap sangat penting dalam menjaga warisan budaya untuk generasi masa depan. Desain kawasan wisata Embung Mekar Sari dapat menjadi pelopor dalam pengembangan Desain Lanskap berbasis Identitas Budaya.

\section{Ucapan Terima Kasih}

Ucapan terima kasih saya sampaikan kepada Pemerintah Kabupaten Tulang Bawang Barat atas izin dan kemudahan yang diperoleh selama pengumpulan data serta kemudahan komunikasi dalam penyampaian hasil kemajuan. Terima kasih juga untuk ITERA serta rekan-rekan dosen dan mahasiswa yang turut membantu dalam selesainya pelaksanaan mulai dari pengumpulan data, perencanaan hingga desain lanskap.

\section{Daftar Pustaka}

Franjaya EE, Gunawan A, Mugnisjah WQ. (2013) Desain Lanskap Pertanian Terpadu sebagai Wahana Pendidikan dan Wisata Pertanian. Jurnal Lanskap Indonesia Vol 5 No 1 2013: 7-15.

UPTD Museum Negeri Provinsi Lampung. (2016). Adat Istiadat Daerah Lampung. Bandar Lampung: Museum Negeri Provinsi Lampung.

Syarief, R. (2012). Pengaruh Warisan Budaya Perahu pada Arsitektur Tradisional di Lampung. Bandar Lampung: CV. Anugrah Utama Raharja. 